resident or exotics in the province (Dobbyn 1994). There is a short introduction that discusses the major habitat types in Ontario, seasonal effects, and mammal watching in the province. Oddly, a map with 12 places to see mammals in Ontario is found 8 pages before the descriptions of some of these Provincial and National Parks. From a practical point of view, only a few of these parks (e.g., Algonquin) are readily accessible whereas others are essentially inaccessible (e.g., Polar Bear). It would have been useful to list some sites in southern Ontario, such as the Bruce Trail along the Niagara Escarpment. The introduction ends with an "About This Book" section going over the taxonomic organization, use of scientific and common names, distribution maps, and the identification of species. It does not, however, review the information or topics presented within each species account.

In general, topics covered in the species accounts include anecdotal natural history facts, other names in addition to the scientific and common name, description of the mammal, its range, habitat, and food; where it sleeps, number of young, and a description of similar species. These topics are interspersed with a combination of distribution map, illustrations, tracks, range of measurements, "Did you know?" sidebar, and usually a photograph. The maps, unfortunately, are difficult to read because the dark shading for presence and light shading for absence is confusing when overlaid on the base map, which is further shaded (with perhaps vegetation?). Occurring several times throughout the book is a duplication of information in the "Did you know?" section and also in the text. In addition, the illustration of a similar species is a reduced version from the original species account. The drawings and photographs are, however, of very good quality.

The species accounts are organized taxonomically by order and family with a brief introduction to each group. Some information in these introductions is unclear and there are no references cited in the text nor is there a bibliography presented at the end of the book to verify any facts. For example, in the carnivore section, skunks are placed in their own family separate from weasels based on recent DNA studies. However, it is

\section{Mammals of North America}

By Roland W. Kays and Don E. Wilson. 2002. Princeton University Press, Princeton. 240 pages, Cloth U.S. \$19.95

This new field guide is just what a field guide should be, small, well-organized and informative. Princeton has adopted the best format of having the animals' illustrations on the right page of each two-page spread, while on the left is the text and distribution map. I've never liked the other formats where the reader must go to up to three different parts of the same guide for these obviously-related pieces of information.

This guide also has several two-page spreads that perhaps were based on the great examples in the Golden also stated that hair seals share a common ancestor with weasels, which is misleading because walruses and skunks are each more closely related to hair seals and weasels, respectively, as was also concluded by the same DNA studies (Dragoo and Honeycutt 1997). The bat and shrew sections each begin with a dichotomous identification key to species, which seems unexpected because none of the other groups has one. The species accounts, which comprise $85 \%$ of the book, are followed by a short glossary and indices to scientific and common names.

My major complaint about this book is that most of the information has been previously published in other mammal field guides by Lone Pine Publishing. This includes sections copied verbatim, in addition to the use of the same photographs and illustrations for species that happen to be found in both areas of interest. This style of "form-letter" field guides leaves very little specific information about the animals in Ontario. There is only generalized information about the species in North America as evidenced by the range descriptions with no details about where the mammal is found in Ontario. Nonetheless, the book presentation is good, although I would have preferred an expanded introduction going deeper into issues such as the role of mammals in the environment and conservation of biodiversity in Ontario. If you already have a book in this series, it may not be absolutely necessary to get another, but one is definitely nice.

\section{Literature Cited}

Cross, E. C., and J. R. Dymond. 1929. The mammals of Ontario. Royal Ontario Museum of Zoology, Handbook Number 1, University of Toronto Press.

Dobbyn, J. S. 1994. Atlas of the mammals of Ontario. Federation of Ontario Naturalists, Don Mills, Ontario.

Dragoo, J. W., and R. L. Honeycutt. 1997. Systematics of mustelidlike carnivores. Journal of Mammalogy 78: 426-443.

Peterson, R. L. 1966. The mammals of eastern Canada. Oxford University Press, Toronto.

BURTON K. LIM

Centre for Biodiversity and Conservation Biology, Royal Ontario Museum, 100 Queen's Park, Toronto, Ontario M5S 2C6 Canada

Guide to Birds of North America. In the latter, all of the confusing warblers, and then all of the sparrows, are illustrated a second time on two-page spreads to help the field biologist or birder more quickly identify these tricky birds. In the Princeton guide, the "confusing cave Chiroptera" are so illustrated, as are bowriding whales and dolphins. Further double-page illustration sets are in black-and-white, and include profiles of breaching and blowing whales, scats, and foot prints. I like these; in the field, these two-page spreads are a joy to use and save much page-flipping.

The illustrations have been created by eleven artists, and as a general comment, I think they are all good. 
To my eye, the mice and vole illustrations are just a bit too cute, and the carnivores look like they've been drawn from mounted specimens...they're somewhat stiff in appearance. With some of the particularly difficult species, illustrations of some bony material accompanies the main image; the opportunity to use this information would likely be restricted to taxonomists or biologists studying carnivore diets. I question the value of, for instance, including chipmunk genital bones in a field guide. This type of material is more apt for specialty publications.

There are a few editorial problems that appear. I found the maps too small and they do not contain the boundary that distinguishes Nunavut from the Northwest Territories. The very odd Aplodontia rufa is listed with the common name of Sewellel; the older name of Mountain Beaver is not mentioned, which makes

\section{The Complete Guide to Antarctic Wildlife}

By Hadoram Shirihai. 2003. Princeton University Press, Princeton and Oxford. 510 pages. U.S. \$49.50.

The ecotraveller to the southern ocean will rejoice at having a single book that covers all the normally occurring birds and mammals of that region. Indeed, this book is much more than a simple field guide. It starts with a synopsis of the region and it ends with detailed descriptions of the major locations of interest, with the species accounts sandwiched in between. This additional material occupies a third of the book, so it contains a substantial amount of information. Included are accounts of geology, geography, habitats, human history and conservation. The regional descriptions explain where the key locations they are situated, what they are like and how to get there. They also explain the birds and mammals most likely to be found, with specific instructions for the difficult-to-locate species.

Ice is a major factor in the lives of all the region's inhabitants. Shirihai has written a handy little section on surface ice, its forms and formation and its features. It took me several weeks of research to collect similar information a few years ago. He does not mention the subsurface ice (which very few people see) that also has many profound effects (damping currents, shielding UV rays, scouring the sea bed, etc.).

The author also does a good job of explaining the ecology and history of the regions. The human history section is a scant seven pages, so it only skips the surface of many remarkable tales. But then this is not a history book.

The Species accounts are well organized and well written. There is a good description of each animal, with a notation about the possible species that could cause confusion in the field. The author also adds a short note on conservation, distribution and biology. A $7 \times 7 \mathrm{~cm}$ range map accompanies most of the species accounts. To avoid the problems of defining the tax- their statement, "Poorly named, this primitive rodent is neither aquatic nor fond of mountains..." seem rather out of place. The Gaspé Shrew range is incomplete, as it is known to occur in Nova Scotia as well. Pappogeomys is listed in the introduction to a plate, but no such genus is mentioned further on, Cratogeomys is used instead. Although the taxonomy of these pocket gophers is in turmoil, this book should have adopted one genus or the other for these rodents.

Overall, this is a very good field guide; with the editorial glitches cleaned up in a second edition, this will be a great field guide.

\section{RANDY LAUFF}

Department of Biology, St. Francis Xavier University, Antigonish, Nova Scotia B2G 2W5 Canada

onomy of some difficult-to-resolve species, the author has treated all forms as species, while noting the alternative taxonomic ideas. This neatly sidesteps the issue for birds that may be split and means the book will not go out of date for a long time. It does make it more difficult to use the index as; for example, Yellow-nosed Albatross is entered as Indian Yellow-nosed and Atlantic Yellow-nose in the albatross section. (That is under I and A and not Y). It does less well for birds that have been lumped. For example; the author lists Buteo polyosoma as Red-backed Hawk. This has been lumped in the more recent texts with Puna Hawk as Variable Hawk (Buteo poecilochrous), so you have to know the alternative, older taxonomy when using the index.

A good example of a species account is the one for Black-browed Albatross. The descriptions are clear and accurate covering adult, juvenile and two ages of immature. There is a description of voice and biometrics. The note on similar forms includes the Campbell Albatross, a split of the tiny Campbell Island population. Apart from the plate containing three depictions there are five photographs - three different ages in flight, a pair displaying and an adult with a fuzzy chick (there are two other photographs in the section on the Falkland Islands). There is a short account of the biology and an accurate current account of the serious conservation issue facing this graceful bird.

There is only one English name given for each species. Those not used to scientific names may have some confusion where the names vary from earlier texts. Many older texts refer to the Pale-faced and Black-faced Sheathbill as American (or Greater) and Lesser Sheathbill, respectively. There is also a poetic and historical loss too. The Striated Caracara is widely, affectionately and historically known as "Johnny Rook." In addition, the author continues to use some of the old English names such as Light-mantled Sooty Albatross over the newer and simpler Light-mantled Albatross. 